\title{
Interfacial Reaction and Microstructure Evolution of Sn-9Zn/Ni(Cu) Solder Joints
}

\author{
Xuewei Zhu ${ }^{1}{ }^{\mathbb{D}}$, Jian Peng ${ }^{2, *}$, Xiaofeng Wei ${ }^{1}$, Pengpeng Yan ${ }^{1}$ and Fu Wang ${ }^{1}$ \\ 1 College of Mechanical and Electronic Engineering, Northwest A\&F University, Yangling 712100, China; \\ zxw_83614@163.com (X.Z.); wxf8412@nwafu.edu.cn (X.W.); yanpengpeng@nwafu.edu.cn (P.Y.); \\ wangfu@nwafu.edu.cn (F.W.) \\ 2 School of Materials Science and Engineering, Central South University, Changsha 410083, China \\ * Correspondence: j.peng@csu.edu.cn; Tel.: +86-158-7410-1500
}

Received: 5 April 2019; Accepted: 22 May 2019; Published: 24 May 2019

\begin{abstract}
Sn}-9 \mathrm{Zn}$ solder is a promising Pb-free solder, but it tends to form bulky intermetallic compounds (IMC) grains at the interface when soldered with common simple metal $\mathrm{Cu}$ or $\mathrm{Ni}$ substrates. Interfacial reaction between $\mathrm{Sn}-9 \mathrm{Zn}$ solder and $\mathrm{Ni}(\mathrm{Cu})$ solid solution substrates at $250{ }^{\circ} \mathrm{C}$ and $350{ }^{\circ} \mathrm{C}$ were systematically probed in this study. Results showed that when soldered at $250^{\circ} \mathrm{C}$, a $\mathrm{Ni}_{5} \mathrm{Zn}_{21}$ layer is formed at $\mathrm{Sn}-\mathrm{Zn} / \mathrm{Ni}-20 \mathrm{Cu}$ and $\mathrm{Sn}-\mathrm{Zn} / \mathrm{Ni}-40 \mathrm{Cu}$ joints; and $\mathrm{Ni}_{2} \mathrm{Sn}_{2} \mathrm{Zn}+\mathrm{Cu}_{5} \mathrm{Zn}_{8}$ and $\mathrm{Cu}_{5} \mathrm{Zn}_{8}$ phases are formed in $\mathrm{Sn}-\mathrm{Zn} / \mathrm{Ni}-60 \mathrm{Cu}$ and $\mathrm{Sn}-\mathrm{Zn} / \mathrm{Ni}-80 \mathrm{Cu}$ joints, respectively. Fine-grained IMCs formed at the interface are formed even when the soldered time is prolonged to $16 \mathrm{~h}$. This result indicates that $\mathrm{Ni}(\mathrm{Cu})$ solid solution substrates inhibit the rapid growth of IMC at the $\mathrm{Sn}-\mathrm{Zn} / \mathrm{Ni}-\mathrm{Cu}$ interface. $\mathrm{Ni}(\mathrm{Cu})$ solid solution substrate can also provide various combinations of reaction products at the $\mathrm{Sn}-\mathrm{Zn} / \mathrm{Ni}-\mathrm{Cu}$ joints. The $\mathrm{Ni}_{5} \mathrm{Zn}_{21}$ transfers to $\mathrm{Ni}_{2} \mathrm{Sn}_{2} \mathrm{Zn}+\mathrm{Cu}_{5} \mathrm{Zn}_{8}$ phases when the $\mathrm{Cu}$ content increased to $60 \%$, and a bi-layered structure $\mathrm{Ni}_{2} \mathrm{Sn}_{2} \mathrm{Zn}+\mathrm{Cu}_{5} \mathrm{Zn}_{8}$ IMCs was formed in $\mathrm{Sn}-\mathrm{Zn} / \mathrm{Ni}(\mathrm{Cu})$ joints at $350{ }^{\circ} \mathrm{C}$ regardless of the $\mathrm{Cu}$ content in $\mathrm{Ni}(\mathrm{Cu})$ substrate $(20-80 \%)$. These results would provide an effective support in designing Sn-Zn soldering system with optimized IMC layer to improve mechanical performance.
\end{abstract}

Keywords: interfacial reaction; intermetallic compound; $\mathrm{Sn}-9 \mathrm{Zn}$ solder; $\mathrm{Ni}(\mathrm{Cu})$ substrates

\section{Introduction}

Soldering is one of the most important packaging methods for electronic industry. During soldering, intermetallic compounds (IMCs) form at the solder/substrate interface. A thin, continuous, and uniform IMC layer provides good bonding for soldered joints. The Sn-9Zn (weight percent) alloy, with the melting point of $183{ }^{\circ} \mathrm{C}$, is a promising $\mathrm{Pb}$-free solder because of its environment-friendly, cost-effective, and good mechanical properties [1-4]. Nevertheless, Sn-9Zn alloy tends to form bulky IMC grains at the interface when $\mathrm{Sn}-9 \mathrm{Zn}$ is soldered with common substrates, such as $\mathrm{Ni}$ and $\mathrm{Cu}$; however, the soldered $\mathrm{Sn}-9 \mathrm{Zn} / \mathrm{Cu}$ and $\mathrm{Sn}-9 \mathrm{Zn} / \mathrm{Ni}$ joints presented poor mechanical performance [5-7]. Generally, with the brittle nature of IMC and the tendency to generate structural defects near interface, the bulky IMC grains deteriorate joint reliability [8-11].

Minor alloying elements are added in Sn-9Zn solder to enhance joint reliability. Most studies focused on the alloying effect on Sn-9Zn solder performance; additional elements can enhance the corrosion resistance, tensile strength, and wettability of Sn-9Zn solder [12-17]. Only limited attention was given to interfacial reaction in soldered joints. However, bulky and irregular IMC grains are still formed at the $\mathrm{Sn}-\mathrm{Zn} / \mathrm{Cu}$ interface when $\mathrm{Al}$ and $\mathrm{Ag}$ are added in the solder [18].

Multielement substrate provides an effective way to change IMC species, morphology, and growth kinetics [19-21]. The interfacial reaction between $\mathrm{Ni}(\mathrm{Cu})$ or $\mathrm{Ni}(\mathrm{Co})$ multielement substrates, and 
Au-20Sn or Sn-Cu solders has been extensively studied [21-24]. Cu alloying in Ni substrate alters the reaction path and induces the formation of thin uniform IMC layers, thereby improving the mechanical reliability of soldered joint [20]. In other words, the mechanical reliability of the joint by using $\mathrm{Ni}(\mathrm{Cu})$ substrate to modify the interfacial reaction products is expected to improve. However, only a few publications reported the interfacial reaction between $\mathrm{Sn}-\mathrm{Zn}$ and $\mathrm{Ni}(\mathrm{Cu})$ substrates. To explore the feasibility and implementation of enhancing the reliability of the Sn-Zn soldered joints by using multielement substrates, we carefully investigated the interfacial reactions between Sn-9Zn solder and $\mathrm{Ni}(\mathrm{Cu})$ substrate at $250{ }^{\circ} \mathrm{C}$ and $350{ }^{\circ} \mathrm{C}$ in this study.

\section{Materials and Methods}

Pure Sn (99.99 wt.\%), Zn (99.9 wt.\%), Ni (99.99 wt.\%), and Cu (99.99 wt.\%) shots were carefully weighed to prepare the Sn-9Zn solder and Cu-Ni $(20,40,60$, or 80 at.\% Ni) substrates. The Sn-9Zn solder and $\mathrm{Ni}(\mathrm{Cu})$ substrates were fabricated by inducing melting in quartz tubes filled with Ar and molten solder casting in the graphite mode. The as-obtained $\mathrm{Sn}-9 \mathrm{Zn}$ and $\mathrm{Ni}(\mathrm{Cu})$ plates, with the thickness of $5 \mathrm{~mm}$, were rolled to 0.1 and $1 \mathrm{~mm}$ thickness, respectively. The $\mathrm{Ni}(\mathrm{Cu})$ was cut into sheets of $5 \mathrm{~mm} \times 5 \mathrm{~mm} \times 1 \mathrm{~mm}$, while $\mathrm{Sn}$-Zn were cut into foils of with the dimension pf $5 \mathrm{~mm} \times 5 \mathrm{~mm} \times 0.1 \mathrm{~mm}$.

Before soldering, $\mathrm{Ni}(\mathrm{Cu})$ sheets were mechanically polished. The substrate sheets and solder foils were cleaned with acetone in an ultrasonic washer for $5 \mathrm{~min}$. The $\mathrm{Sn}-9 \mathrm{Zn}$ foil was placed between two $\mathrm{Ni}(\mathrm{Cu})$ sheets (Figure 1) in a furnace in Ar atmosphere at $250{ }^{\circ} \mathrm{C}$ for $1,4,9$, and $16 \mathrm{~h}$ or at $350{ }^{\circ} \mathrm{C}$ for 2 , 10 , and $60 \mathrm{~min}$ and then cooled in air.

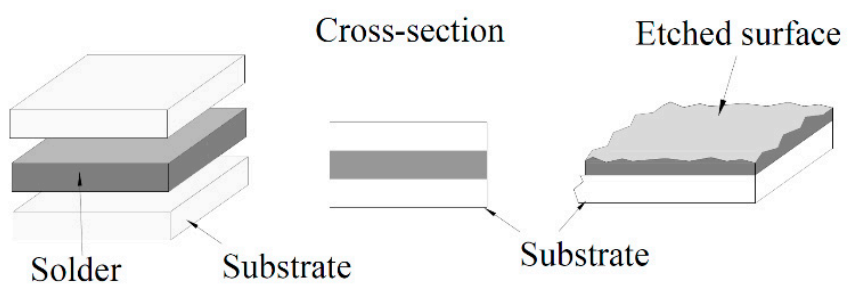

Figure 1. Schematic diagram of $\mathrm{Sn}-\mathrm{Zn} / \mathrm{Ni}(\mathrm{Cu})$ joints.

The soldered samples for electro-probe microanalysis (EPMA) were mechanically polished in the direction normal to the soldering interface. Shimadzu XRD-6000 X-ray diffraction (XRD) instrument, with $\mathrm{Cu} \mathrm{K} \alpha$ radiation (wavelength $0.154 \mathrm{~nm}$ ) at $40 \mathrm{kV}$ and a tube current of $30 \mathrm{~m} \AA$, was used to measure the phase constitution of the reaction layers with the scanning rate of $1 \mathrm{deg} / \mathrm{min}$. To analyze the ternary reaction products accurately, we tensile fractured the soldered joints. Then, the Sn-Zn solder matrix was removed using 5\% $\mathrm{HCl}$ water solution and cleaned with acetone in an ultrasonic washer for $5 \mathrm{~min}$. The etched surface was perpendicular to cross-section. The etched interfacial microstructure of the joints was further analyzed by scanning electron microscopy (SEM) equipped with an energy dispersive spectrometer.

\section{Results and Discussions}

\subsection{Reaction Products in Sn-Zn/Ni-20Cu Joint}

Two reaction layers formed in $\mathrm{Sn}-\mathrm{Zn} / \mathrm{Ni}-20 \mathrm{Cu}$ joints after soldering at $250{ }^{\circ} \mathrm{C} \mathrm{Ni}-2016 \mathrm{~h}$ according to the back-scattered electron (BSE) micrograph (Figure 2a). EPMA result revealed that dark phase-composited Ni-74.7Zn-11.4Cu-1.3Sn (at.\%) can be designated as $\mathrm{Ni}_{5} \mathrm{Zn}_{21}$ phase according to $\mathrm{Ni}-\mathrm{Zn}-\mathrm{Cu}$ isothermal section at $250{ }^{\circ} \mathrm{C}$. The reaction product formed between $\mathrm{Ni}_{5} \mathrm{Zn}_{21}$ phase and $\mathrm{Ni}-20 \mathrm{Cu}$ substrate, with the composition of Ni-20.2Zn-7.7Cu-40.8Sn. According to the equilibrium phase diagram of $\mathrm{Sn}-\mathrm{Zn}-\mathrm{Ni}$ and $\mathrm{Sn}-\mathrm{Zn}-\mathrm{Cu}$ system at $250{ }^{\circ} \mathrm{C}$, several ternary phases contained approximately 
20 at. $\%$ Zn and 40 at.\% Sn, as presented in Table 1 . It may be a ternary compound, but directly defining the phase constitution only by EPMA measurement is difficult.
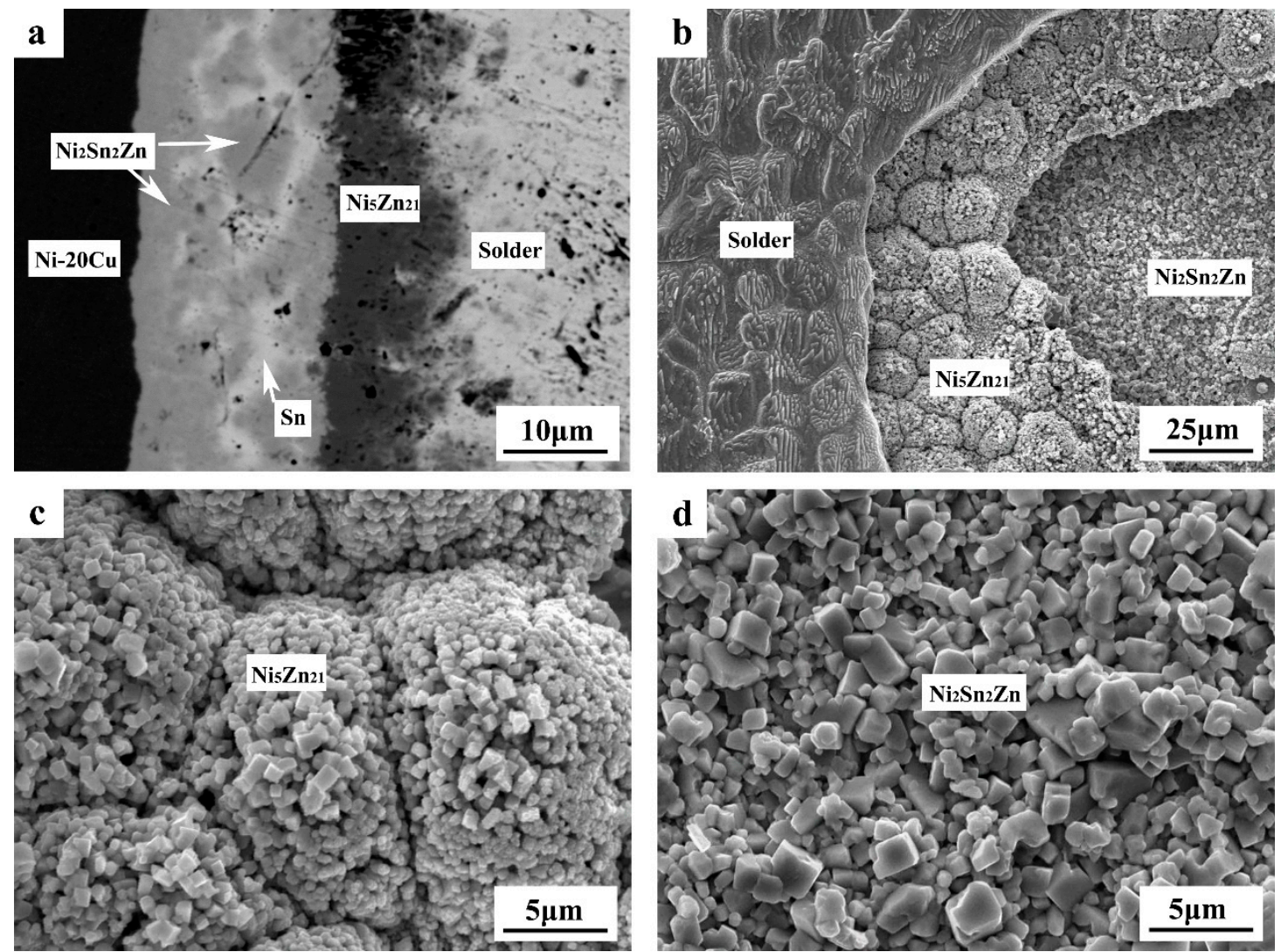

Figure 2. The Sn-Zn/Ni-20Cu joint of $16 \mathrm{~h}$ soldering at $250{ }^{\circ} \mathrm{C}$ : (a) cross-section micrograph; (b) Etched interface; (c) morphology of $\mathrm{Ni}_{5} \mathrm{Zn}_{21}$ grains; (d) morphology of $\mathrm{Ni}_{2} \mathrm{Sn}_{2} \mathrm{Zn}$ grains.

To analyze the ternary reaction products accurately, we removed the Sn-Zn solder matrix, and the etched surface was further characterized by SEM (FEI Corporation, Hillsboro, OR, USA) and XRD (Rigaku Corporation, Tokyo, Japan). All the three layers, that is, solder matrix, $\mathrm{Ni}_{5} \mathrm{Zn}_{21}$, and undefined ternary compounds layer, can be directly observed in the etched surface (Figure 2b). The XRD pattern of the etched surface is presented in Figure 3. The Ni-20Cu (PDF, 04-0850), Sn (PDF, 04-0673), and $\mathrm{Ni}_{5} \mathrm{Zn}_{21}$ (PDF, 04-0850) phases can be identified directly. Other diffraction peaks are identical with the $\tau 3$ phase, as reported by Schmetterer [25], which can be designated as the $\mathrm{Ni}_{2} \mathrm{Sn}_{2} \mathrm{Zn}$ phase [26].

Table 1. Ternary phases contained about 20 at. \% Zn and 40 at.\% Sn found in the system Ni-Sn-Zn [25-31].

\begin{tabular}{ccccc}
\hline \multirow{2}{*}{ Nomenclature } & \multicolumn{3}{c}{ Composition Phase Name } & \multirow{2}{*}{ Refs. } \\
\cline { 2 - 4 } & $\mathbf{N i}$ & Sn & Zn & \\
\hline $\mathrm{T} 1$ & 36.0 & 38.0 & 26.0 & {$[27,28]$} \\
$\tau 2$ & 38.5 & 35.7 & 25.8 & {$[29]$} \\
$\delta$ & 36.8 & 38.8 & 24.4 & {$[30]$} \\
$\tau 1$ & 49.7 & 36.6 & 13.7 & {$[30]$} \\
$\delta$ & 31.8 & 44.5 & 23.7 & {$[31]$} \\
$\tau 3$ & 33.3 & 42.8 & 23.8 & {$[25]$} \\
$\mathrm{Ni}_{2} \mathrm{Sn}_{2} \mathrm{Zn}$ & 40.0 & 40.0 & 20.0 & {$[26]$} \\
\hline
\end{tabular}




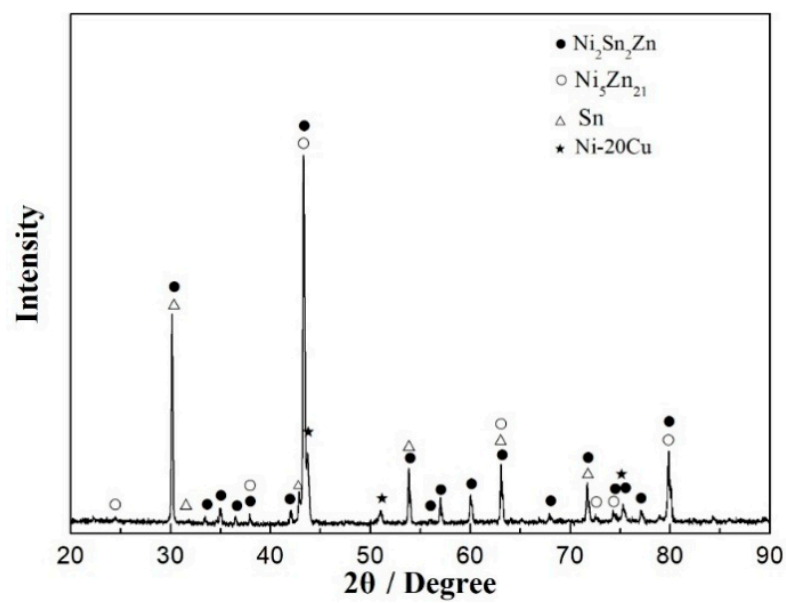

Figure 3. The X-ray diffraction (XRD) pattern of etched interface of $\mathrm{Sn}-\mathrm{Zn} / \mathrm{Ni}-20 \mathrm{Cu}$ joint after soldered at $250{ }^{\circ} \mathrm{C}$ for $16 \mathrm{~h}$.

Figure 4 illustrates the BSE micrographs and XRD patterns of $\mathrm{Sn}-\mathrm{Zn} / \mathrm{Ni}-20 \mathrm{Cu}$ couple after reaction at $250{ }^{\circ} \mathrm{C}$ for 1 and $9 \mathrm{~h}$. Only a $\mathrm{Ni}_{5} \mathrm{Zn}_{21}$ layer formed at the interface after $9 \mathrm{~h}$ of soldering. The loose $\mathrm{Ni}_{5} \mathrm{Zn}_{21}$ layer was formed at the interface after $1 \mathrm{~h}$ of soldering. Meanwhile, after $9 \mathrm{~h}$, a dense $\mathrm{Ni}_{5} \mathrm{Zn}_{21}$ layer was formed.
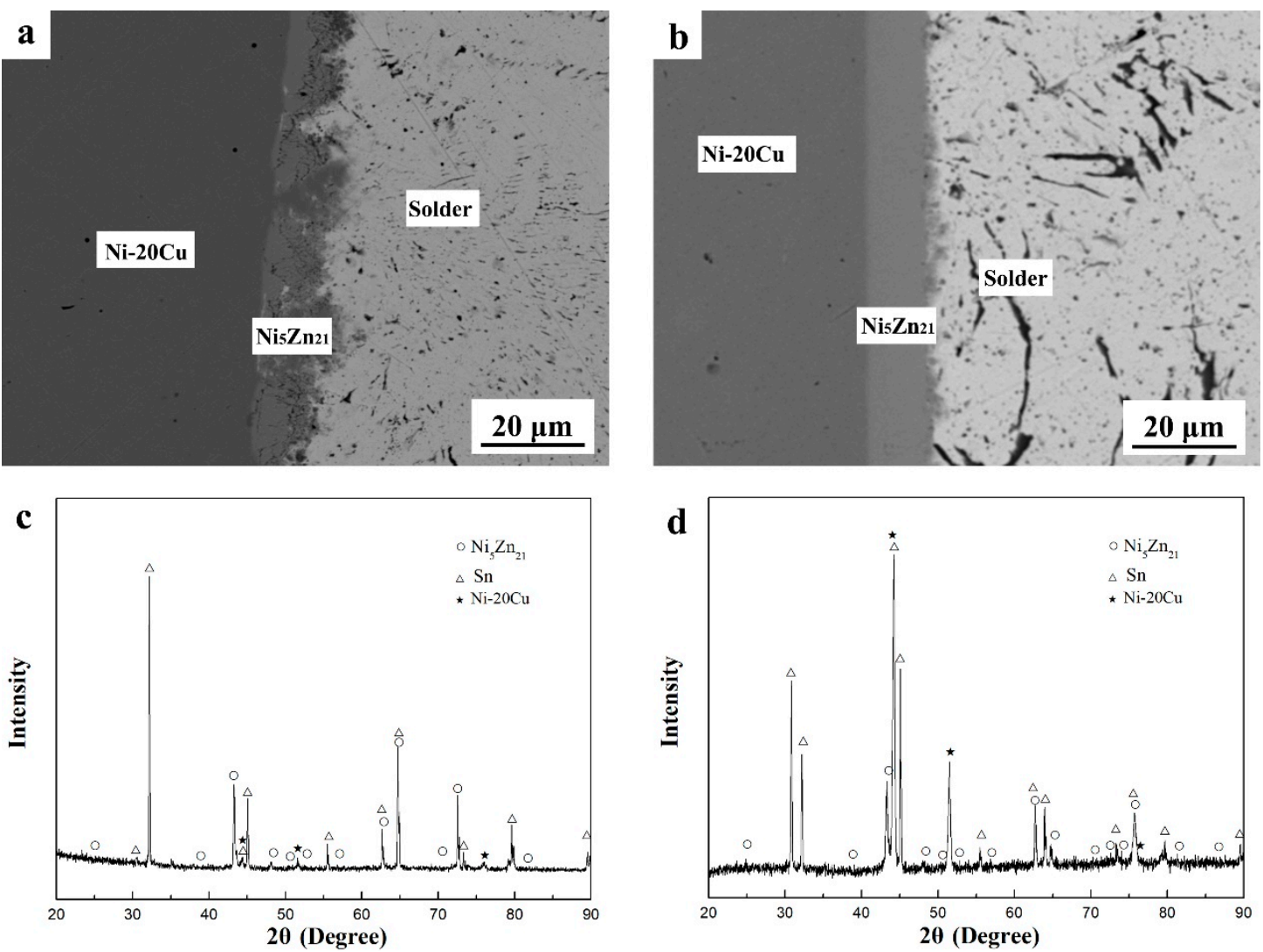

Figure 4. Cross-section micrographs $(\mathbf{a}, \mathbf{b})$ and X-ray diffraction $(\mathrm{XRD})$ patterns $(\mathbf{c}, \mathbf{d})$ of $\mathrm{Sn}-\mathrm{Zn} / \mathrm{Ni}-20 \mathrm{Cu}$ joints after soldered at $250{ }^{\circ} \mathrm{C}$ for $1 \mathrm{~h}(\mathbf{a}, \mathbf{c})$ and $9 \mathrm{~h}(\mathbf{b}, \mathbf{d})$.

\subsection{Effect of $\mathrm{Cu}$ Content on Reaction Products}

Figure 5 shows the BSE micrographs and XRD patterns of $\mathrm{Sn}-\mathrm{Zn} / \mathrm{Ni}-\mathrm{Cu}$ couples after reaction at $250^{\circ} \mathrm{C}$ for $9 \mathrm{~h}$, and the compositions of each reaction products are listed in Table 2. As shown in the table, 
the $\mathrm{Cu}$ content in the substrate exerted considerable effect on the interfacial reaction products. When $\mathrm{Sn}-9 \mathrm{Zn}$ solder reacted with $\mathrm{Ni}-40 \mathrm{Cu}$ substrate, a uniform $\mathrm{Ni}_{5} \mathrm{Zn}_{21}$ layer was formed at the interface. However, two reaction layers, namely, $\mathrm{Ni}_{2} \mathrm{Sn}_{2} \mathrm{Zn}$ and $\mathrm{Cu}_{5} \mathrm{Zn}_{8}$, were formed in $\mathrm{Sn}-\mathrm{Zn} / \mathrm{Ni}-60 \mathrm{Cu}$, and $\mathrm{Cu}_{5} \mathrm{Zn}_{8}$ and $\mathrm{CuZn}$ layers appeared in $\mathrm{Sn}-\mathrm{Zn} / \mathrm{Ni}-80 \mathrm{Cu}$.
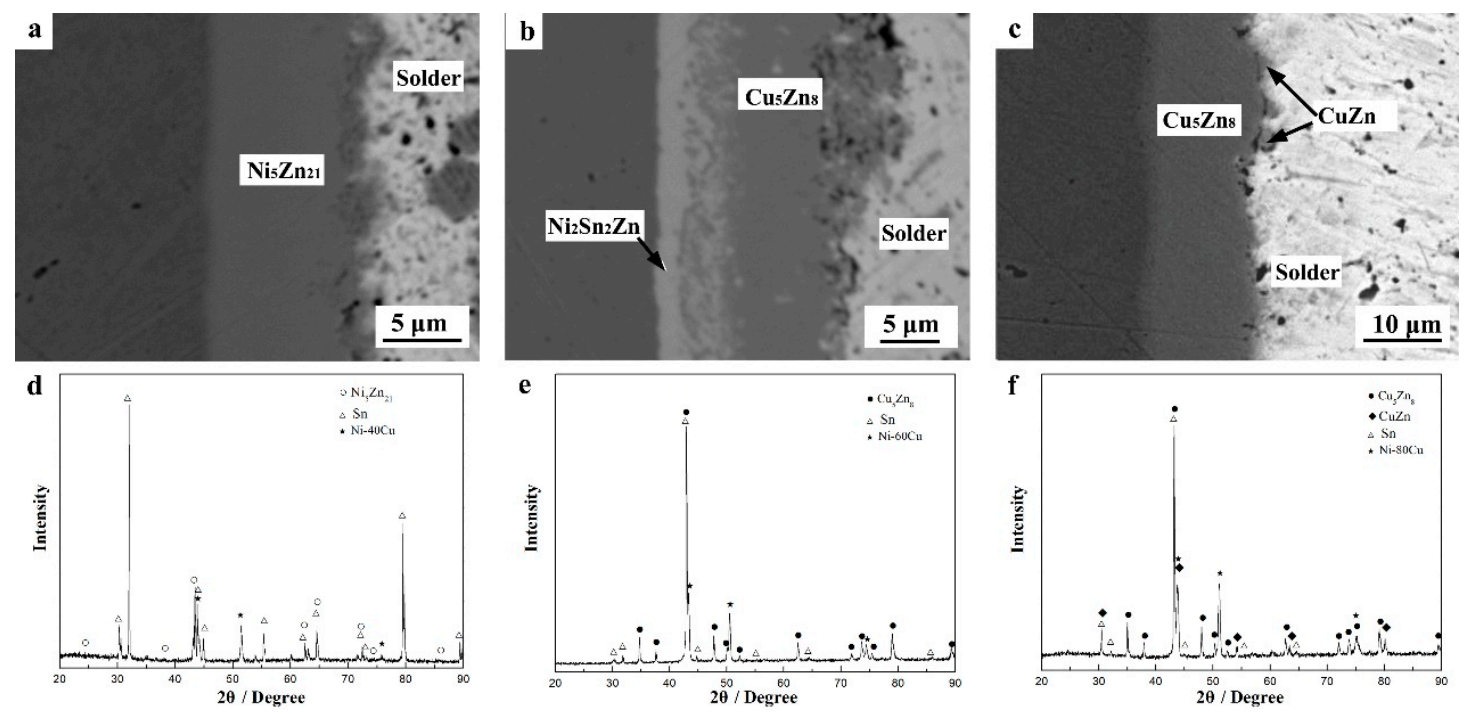

Figure 5. Cross-section micrographs and $X$-ray diffraction $(X R D)$ patterns of etched interface of joints after soldered 9 h at $250{ }^{\circ} \mathrm{C}$ : (a,d) Sn-Zn/Ni-40Cu; (b,e) Sn-Zn/Ni-60Cu; (c,f) Sn-Zn/Ni-80Cu.

Table 2. The composition of reaction products in $\mathrm{Sn}-\mathrm{Zn} / \mathrm{Ni}-\mathrm{Cu}$ joints after soldered at $250{ }^{\circ} \mathrm{C}$ for $9 \mathrm{~h}$.

\begin{tabular}{cccccc}
\hline \multirow{2}{*}{ Substrate } & \multicolumn{4}{c}{ Compositions (at.\%) } & \multirow{2}{*}{ Phase } \\
\cline { 2 - 5 } & $\mathbf{N i}$ & $\mathbf{C u}$ & $\mathrm{Sn}$ & $\mathbf{Z n}$ & \\
\hline $\mathrm{Ni}-20 \mathrm{Cu}$ & 16.44 & 1.98 & 1.45 & 80.13 & $\mathrm{Ni}_{5} \mathrm{Zn}_{21}$ \\
$\mathrm{Ni}-40 \mathrm{Cu}$ & 14.94 & 9.25 & 0.31 & 75.50 & $\mathrm{Ni}_{5} \mathrm{Zn}_{21}$ \\
& 26.12 & 16.91 & 41.95 & 15.01 & $\mathrm{Ni}_{2} \mathrm{Sn}_{2} \mathrm{Zn}$ \\
$\mathrm{Ni}-60 \mathrm{Cu}$ & 8.87 & 21.74 & 1.75 & 67.64 & $\mathrm{Cu}_{5} \mathrm{Zn}_{8}$ \\
& 5.61 & 27.97 & 1.24 & 65.17 & $\mathrm{Cu}_{5} \mathrm{Zn}_{8}$ \\
$\mathrm{Ni}-80 \mathrm{Cu}$ & 5.17 & 35.32 & 8.43 & 51.08 & $\mathrm{CuZn}$ \\
\hline
\end{tabular}

$\mathrm{Cu}$ content in substrate also altered the morphology of the products. Figure 6 illustrates the etched surface of $\mathrm{Sn}-\mathrm{Zn} / \mathrm{Ni}-\mathrm{Cu}$ joint after reaction at $250{ }^{\circ} \mathrm{C}$ for $9 \mathrm{~h}$. In the $\mathrm{Ni}_{5} \mathrm{Zn}_{21}$ phase in $\mathrm{Sn}-\mathrm{Zn} / \mathrm{Ni}-20 \mathrm{Cu}$ and $\mathrm{Sn}-\mathrm{Zn} / \mathrm{Ni}-40 \mathrm{Cu}$ joints, extremely fine $\mathrm{Ni}_{5} \mathrm{Zn}_{21}$ grains constituted the layer in $\mathrm{Sn}-\mathrm{Zn} / \mathrm{Ni}-20 \mathrm{Cu}$ joint, and the spherical $\mathrm{Ni}_{5} \mathrm{Zn}_{21}$ particles formed at interface in $\mathrm{Sn}-\mathrm{Zn} / \mathrm{Ni}-40 \mathrm{Cu}$ joints. A dense $\mathrm{Cu}_{5} \mathrm{Zn}_{8}$ layer was formed in the $\mathrm{Sn}-\mathrm{Zn} / \mathrm{Ni}-60 \mathrm{Cu}$ joint, while a dense $\mathrm{Cu}_{5} \mathrm{Zn}_{8}$ layer with some $\mathrm{CuZn}$ grains was formed in the $\mathrm{Sn}-\mathrm{Zn} / \mathrm{Ni}-80 \mathrm{Cu}$ joint.

The solid solution element in reaction IMCs played a significant role in IMC morphology. As reported in most references, bulky $\mathrm{Cu}_{5} \mathrm{Zn}_{8}$ grains are formed in the $\mathrm{Sn}-\mathrm{Zn} / \mathrm{Cu}$ joint during long reaction time, which extremely deteriorates the joint reliability [5,11]. However, the fine-grained $\mathrm{Cu}_{5} \mathrm{Zn}_{8}$ layer was formed in $\mathrm{Sn}-\mathrm{Zn} / \mathrm{Ni}-60 \mathrm{Cu}$ and $\mathrm{Sn}-\mathrm{Zn} / \mathrm{Ni}-80 \mathrm{Cu}$ joints when $5-9$ at.\% Ni was dissolved in the $\mathrm{Cu}_{5} \mathrm{Zn}_{8}$ phase. 

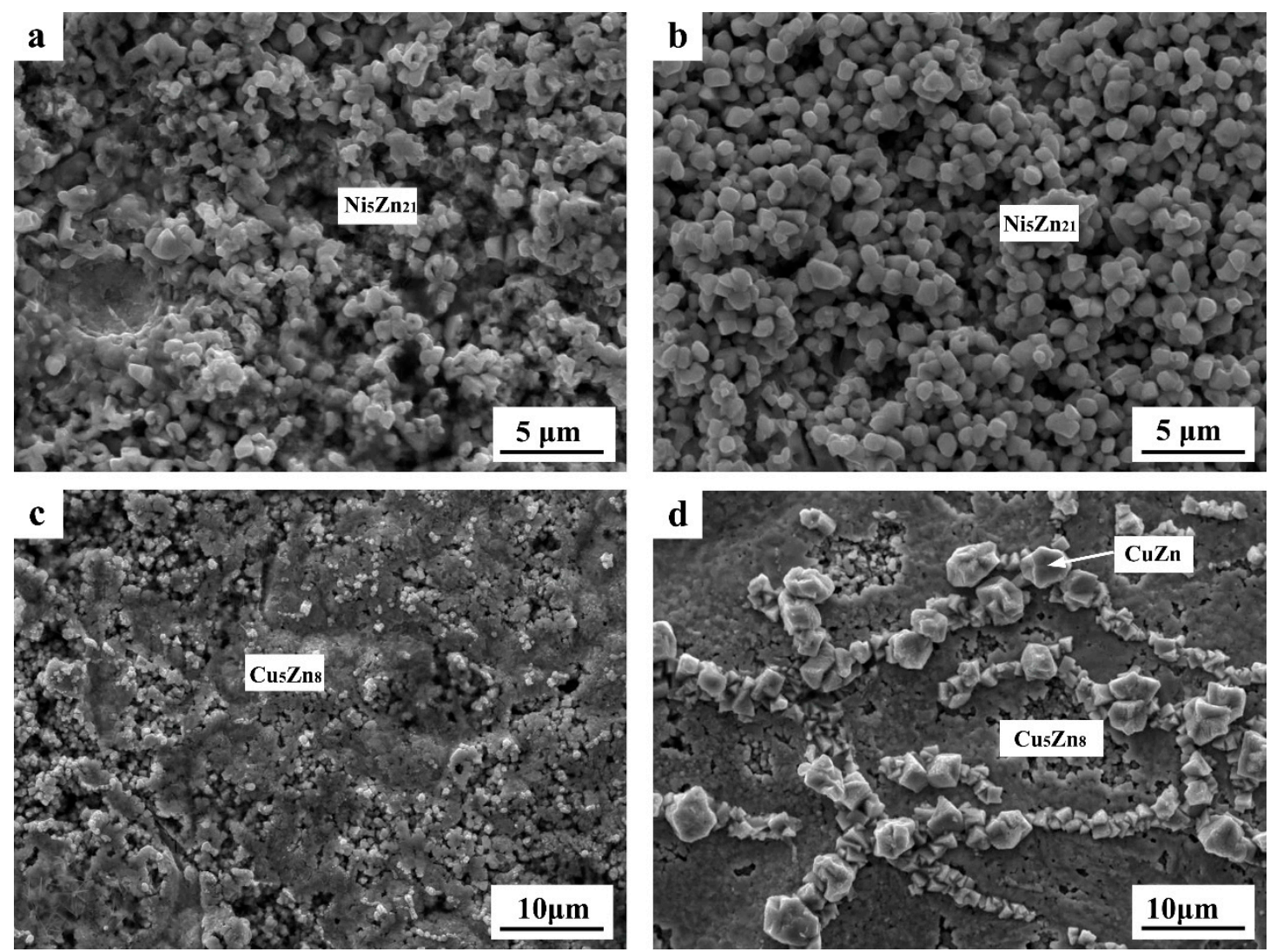

Figure 6. Etched surface micrograph of joints after soldered $9 \mathrm{~h}$ at $250{ }^{\circ} \mathrm{C}$ : (a) $\mathrm{Sn}-\mathrm{Zn} / \mathrm{Ni}-20 \mathrm{Cu}$; (b) $\mathrm{Sn}-\mathrm{Zn} / \mathrm{Ni}-40 \mathrm{Cu}$; (c) Sn-Zn/Ni-60Cu; (d) Sn-Zn/Ni-80Cu.

Table 3 summarizes the interfacial reaction products of $\mathrm{Sn}-\mathrm{Zn} / \mathrm{Ni}-\mathrm{Cu}$ after soldering at $250{ }^{\circ} \mathrm{C}$ for various durations. Hence, $\mathrm{Ni}_{5} \mathrm{Zn}_{21}$ is the first formed product in $\mathrm{Ni}-20 \mathrm{Cu}$ and $\mathrm{Ni}-40 \mathrm{Cu}$ joints, whereas the $\mathrm{Cu}_{5} \mathrm{Zn}_{8}$ phase is the first formed product in Ni-60Cu and Ni-80Cu joints. After prolonging the reaction time, $\mathrm{Ni}_{2} \mathrm{Sn}_{2} \mathrm{Zn}$ phase was formed between the first formed product and substrate. $\mathrm{Ni}_{2} \mathrm{Sn}_{2} \mathrm{Zn}$ was formed in $\mathrm{Sn}-\mathrm{Zn} / \mathrm{Ni}-60 \mathrm{Cu}$ joint only after $1 \mathrm{~h}$ of soldering but appeared in all joints after $16 \mathrm{~h}$.

Table 3. Interfacial reaction products of $\mathrm{Sn}-\mathrm{Zn} / \mathrm{Ni}-\mathrm{Cu}$ after various durations at $250{ }^{\circ} \mathrm{C}$.

\begin{tabular}{|c|c|c|c|c|}
\hline \multirow{2}{*}{ Substrates } & \multicolumn{4}{|c|}{ Soldering Time (h) } \\
\hline & 1 & 4 & 9 & 16 \\
\hline $\mathrm{Ni}-20 \mathrm{Cu}$ & $\mathrm{Ni}_{5} \mathrm{Zn}_{21}$ & $\mathrm{Ni}_{5} \mathrm{Zn}_{21}$ & $\mathrm{Ni}_{5} \mathrm{Zn}_{21}$ & $\mathrm{Ni}_{2} \mathrm{Sn}_{2} \mathrm{Zn}+\mathrm{Ni}_{5} \mathrm{Zn}_{21}$ \\
\hline $\mathrm{Ni}-40 \mathrm{Cu}$ & $\mathrm{Ni}_{5} \mathrm{Zn}_{21}$ & $\mathrm{Ni}_{5} \mathrm{Zn}_{21}$ & $\mathrm{Ni}_{5} \mathrm{Zn}_{21}$ & $\mathrm{Ni}_{2} \mathrm{Sn}_{2} \mathrm{Zn}+\mathrm{Ni}_{5} \mathrm{Zn}_{21}$ \\
\hline $\mathrm{Ni}-60 \mathrm{Cu}$ & $\mathrm{Ni}_{2} \mathrm{Sn}_{2} \mathrm{Zn}+\mathrm{Cu}_{5} \mathrm{Zn}_{8}$ & $\mathrm{Ni}_{2} \mathrm{Sn}_{2} \mathrm{Zn}+\mathrm{Cu}_{5} \mathrm{Zn}_{8}$ & $\mathrm{Ni}_{2} \mathrm{Sn}_{2} \mathrm{Zn}+\mathrm{Cu}_{5} \mathrm{Zn}_{8}$ & $\mathrm{Ni}_{2} \mathrm{Sn}_{2} \mathrm{Zn}+\mathrm{CuZn}$ \\
\hline $\mathrm{Ni}-80 \mathrm{Cu}$ & $\mathrm{Cu}_{5} \mathrm{Zn}_{8}$ & $\mathrm{Cu}_{5} \mathrm{Zn}_{8}$ & $\mathrm{Cu}_{5} \mathrm{Zn}_{8}+\mathrm{CuZn}$ & $\mathrm{Ni}_{2} \mathrm{Sn}_{2} \mathrm{Zn}+\mathrm{CuZn}$ \\
\hline
\end{tabular}

\subsection{Effect of Soldering Temperature on Reaction Products}

When the soldering temperature increased to $350{ }^{\circ} \mathrm{C}, \mathrm{Ni}_{2} \mathrm{Sn}_{2} \mathrm{Zn}+\mathrm{Cu}_{5} \mathrm{Zn}_{8}$ phases appeared at the interface regardless of the $\mathrm{Cu}$ content in $\mathrm{Ni}-\mathrm{Cu}$ substrates after short soldering time, that is, $2 \mathrm{~min}$ (Figure 7). Nevertheless, the volume fraction of $\mathrm{Cu}_{5} \mathrm{Zn}_{8}$ increased with the increase in $\mathrm{Cu}$ content in the substrate. Only few $\mathrm{Cu}_{5} \mathrm{Zn}_{8}$ grains appeared in the $\mathrm{Sn}-\mathrm{Zn} / \mathrm{Ni}-20 \mathrm{Cu}$ and $\mathrm{Sn}-\mathrm{Zn} / \mathrm{Ni}-40 \mathrm{Cu}$ joints, but a $\mathrm{Cu}_{5} \mathrm{Zn}_{8}$ layer occurred between $\mathrm{Ni}_{2} \mathrm{Sn}_{2} \mathrm{Zn}$ and solder matrix when the $\mathrm{Cu}$ content in the substrate was $>60 \%$. 

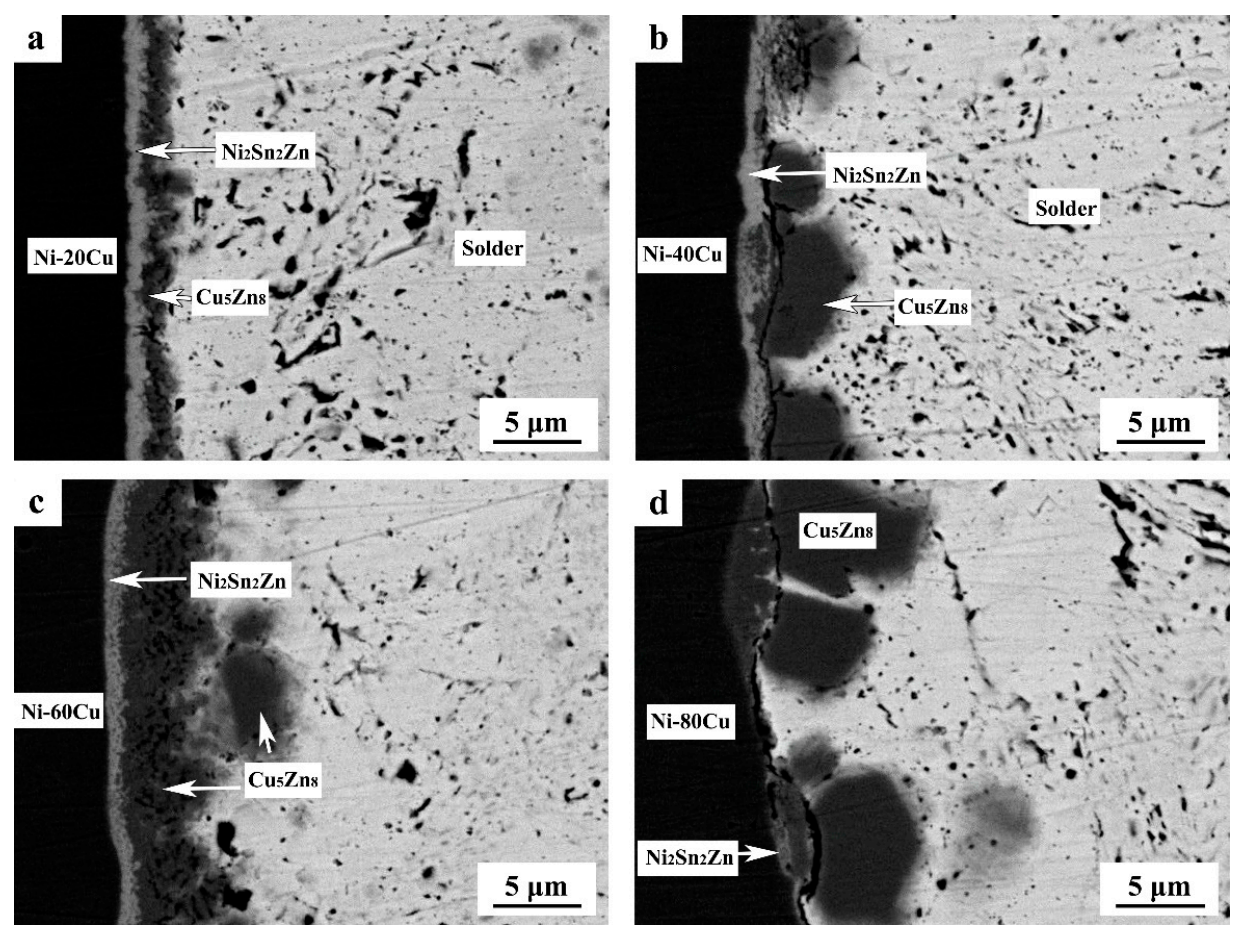

Figure 7. Cross-section micrograph of joints after soldered 2 min at $350{ }^{\circ} \mathrm{C}$ : (a) $\mathrm{Sn}-\mathrm{Zn} / \mathrm{Ni}-20 \mathrm{Cu}$; (b) Sn-Zn/Ni-40Cu; (c) Sn-Zn/Ni-60Cu; (d) Sn-Zn/Ni-80Cu.

Figure 8 presents the interfacial reaction products of $\mathrm{Sn}-\mathrm{Zn} / \mathrm{Ni}-\mathrm{Cu}$ joints after soldering at $350{ }^{\circ} \mathrm{C}$ for $60 \mathrm{~min}$. $\mathrm{Ni}_{3} \mathrm{Sn}_{4}$ phase formed at the $\mathrm{Sn}-\mathrm{Zn} / \mathrm{Ni}-20 \mathrm{Cu}$ interface, while mainly $\mathrm{Ni}_{2} \mathrm{Sn}_{2} \mathrm{Zn}$ phase was formed when $\mathrm{Cu}$ content in the substrate was $>20 \%$. CuZn grains also appeared in Sn-Zn/Ni-60Cu and $\mathrm{Sn}-\mathrm{Zn} / \mathrm{Ni}-80 \mathrm{Cu}$ joints. The interfacial reaction products in $\mathrm{Sn}-\mathrm{Zn} / \mathrm{Ni}-\mathrm{Cu}$ joints after various durations at $350{ }^{\circ} \mathrm{C}$ are listed in Table 4.
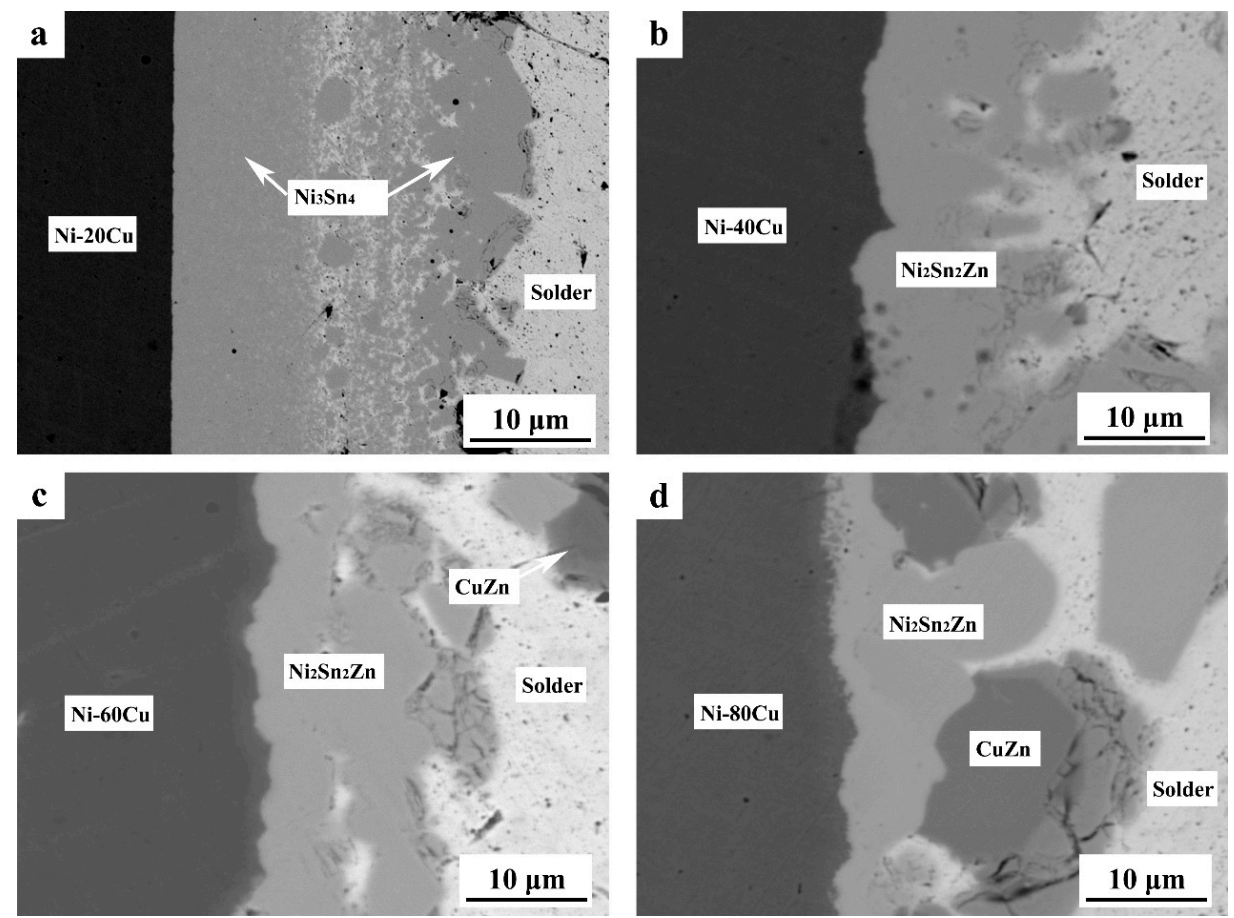

Figure 8. Cross-section micrograph of joints after soldered $60 \mathrm{~min}$ at $350{ }^{\circ} \mathrm{C}$ : (a) $\mathrm{Sn}-\mathrm{Zn} / \mathrm{Ni}-20 \mathrm{Cu}$; (b) Sn-Zn/Ni-40Cu; (c) Sn-Zn/Ni-60Cu; (d) Sn-Zn/Ni-80Cu. 
Table 4. Interfacial reaction products of $\mathrm{Sn}-\mathrm{Zn} / \mathrm{Ni}-\mathrm{Cu}$ after various durations at $350{ }^{\circ} \mathrm{C}$.

\begin{tabular}{cccc}
\hline \multirow{2}{*}{ Substrates } & \multicolumn{3}{c}{ Soldering Time } \\
\cline { 2 - 4 } & $\mathbf{2}$ min & $\mathbf{1 0 ~}$ min & $\mathbf{6 0}$ min \\
\hline $\mathrm{Ni}-20 \mathrm{Cu}$ & $\mathrm{Ni}_{2} \mathrm{Sn}_{2} \mathrm{Zn}+\mathrm{Cu}_{5} \mathrm{Zn}_{8}$ & $\mathrm{Ni}_{2} \mathrm{Sn}_{2} \mathrm{Zn}+\mathrm{Cu}_{5} \mathrm{Zn}_{8}$ & $\mathrm{Ni}_{3} \mathrm{Sn}_{4}$ \\
$\mathrm{Ni}-40 \mathrm{Cu}$ & $\mathrm{Ni}_{2} \mathrm{Sn}_{2} \mathrm{Zn}+\mathrm{Cu}_{5} \mathrm{Zn}_{8}$ & $\mathrm{Ni}_{2} \mathrm{Sn}_{2} \mathrm{Zn}+\mathrm{Cu}_{5} \mathrm{Zn}_{8}$ & $\mathrm{Ni}_{2} \mathrm{Sn} \mathrm{n}_{2} \mathrm{Zn}$ \\
$\mathrm{Ni}-60 \mathrm{Cu}$ & $\mathrm{Ni}_{2} \mathrm{Sn}_{2} \mathrm{Zn}+\mathrm{Cu}_{5} \mathrm{Zn}_{8}$ & $\mathrm{Ni}_{2} \mathrm{Sn}_{2} \mathrm{Zn}+\mathrm{Cu}_{5} \mathrm{Zn}_{8}$ & $\mathrm{Ni}_{2} \mathrm{Sn}_{2} \mathrm{Zn}+\mathrm{CuZn}$ \\
$\mathrm{Ni}-80 \mathrm{Cu}$ & $\mathrm{Ni}_{2} \mathrm{Sn}_{2} \mathrm{Zn}+\mathrm{Cu}_{5} \mathrm{Zn}_{8}$ & $\mathrm{Ni}_{2} \mathrm{Sn}_{2} \mathrm{Zn}+\mathrm{Cu}_{5} \mathrm{Zn}_{8}$ & $\mathrm{Ni}_{2} \mathrm{Sn}_{2} \mathrm{Zn}+\mathrm{CuZn}$ \\
\hline
\end{tabular}

\subsection{Discussions}

It is generally accepted that joint reaction occurs in two steps: (1) solidification preceded by the substrate dissolution; and (2) some transformations in the solid [32,33]. Considering the evolution of interfacial microstructure, two reaction stages can be roughly determined for the interfacial reaction between $\mathrm{Sn}-\mathrm{Zn}$ solder and Ni-Cu substrate, as demonstrated in Figures 9 and 10. Given that no quaternary phase in $\mathrm{Zn}-\mathrm{Sn}-\mathrm{Ni}-\mathrm{Cu}$ system has been reported or detected thus far, the possible reaction paths of Sn-9Zn/Ni-Cu couples were proposed according to the Ni-Sn-Zn [25-31] and Cu-Sn-Zn [34] isothermal sections at 250 and $350^{\circ} \mathrm{C}$, and no other phases were suspended. In addition, the reactions are peritectic reaction according to the Ni-Sn-Zn [25-31] and Cu-Sn-Zn [34] phase diagram at 250 and $350{ }^{\circ} \mathrm{C}$. The solid substrates or reaction product react with liquid and form new reaction products.
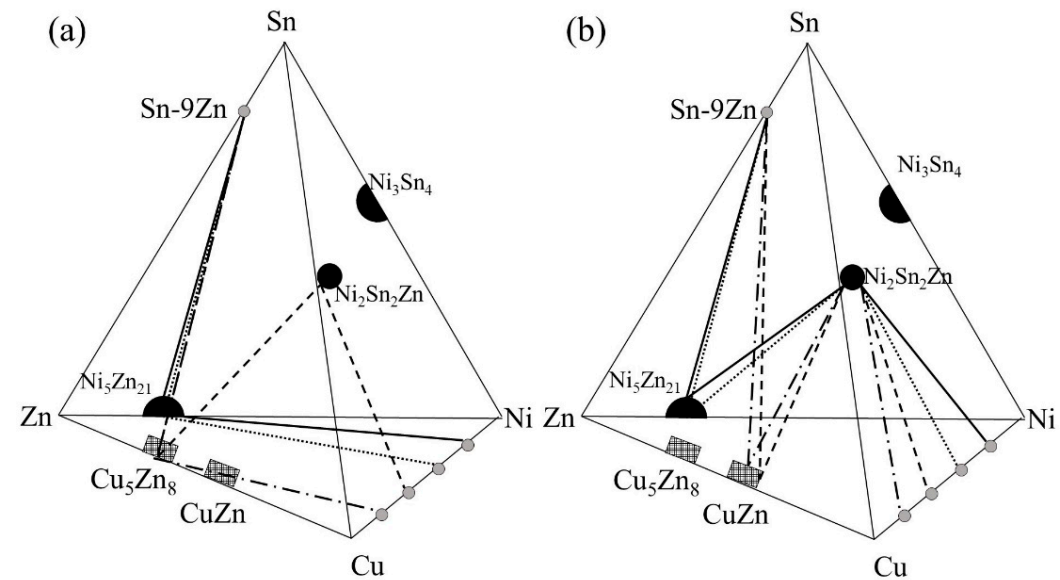

Figure 9. Two reaction stages of the $\mathrm{Sn}-\mathrm{Zn} / \mathrm{Ni}(\mathrm{Cu})$ joints superimpose on the $\mathrm{Zn}-\mathrm{Sn}-\mathrm{Ni}-\mathrm{Cu}$ isothermal tetrahedron at $250{ }^{\circ} \mathrm{C}$ during (a) early stage; and (b) later stage.
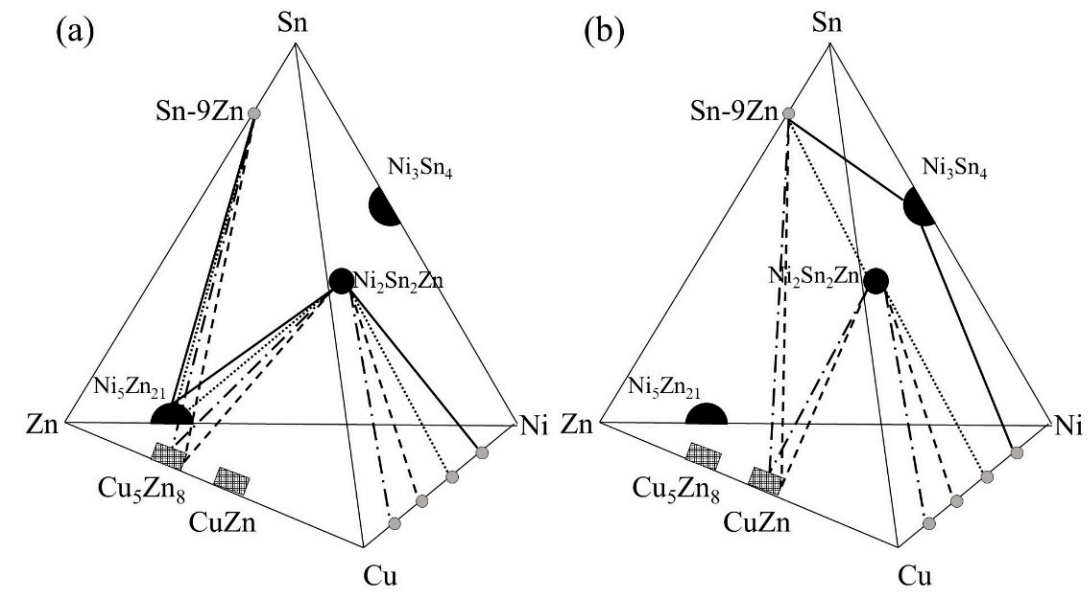

Figure 10. Two reaction stages of the $\mathrm{Sn}-\mathrm{Zn} / \mathrm{Ni}(\mathrm{Cu})$ joints superimpose on the $\mathrm{Zn}-\mathrm{Sn}-\mathrm{Ni}$-Cu isothermal tetrahedron at $350{ }^{\circ} \mathrm{C}$ during (a) early stage; and (b) later stage. 
The monolayered IMC structure appeared first after soldering at $250{ }^{\circ} \mathrm{C}$. Meanwhile, bi-layered IMC structure was observed at $350^{\circ} \mathrm{C}$. As listed in Tables 3 and $4, \mathrm{Ni}_{5} \mathrm{Zn}_{21}$ was the first formed product in Ni-20Cu and Ni-40Cu joints, whereas $\mathrm{Ni}_{2} \mathrm{Sn}_{2} \mathrm{Zn}+\mathrm{Cu}_{5} \mathrm{Zn}_{8}$ phases in Ni-60Cu and $\mathrm{Cu}_{5} \mathrm{Zn}_{8}$ phase in $\mathrm{Ni}-80 \mathrm{Cu}$. However, $\mathrm{Ni}_{2} \mathrm{Sn}_{2} \mathrm{Zn}+\mathrm{Cu}_{5} \mathrm{Zn}_{8}$ phases were always formed at $350{ }^{\circ} \mathrm{C}$ as it always had $\mathrm{Cu}$ content in $\mathrm{Ni}(\mathrm{Cu})$ substrate $(20-80 \%)$.

Thermodynamic and kinetic factors determine the interfacial reaction products during soldering process [35]. The reaction products generally tend to be controlled by the diffusivity of the reactant in the reaction zone [10]. In most cases, only an IMC layer forms at the interface at first, even when solder reacts with binary substrate, because one element in substrate would dominate the interfacial reaction. For example, $\mathrm{Ni}$ is the dominant reaction element in $\mathrm{Ni}-20 \mathrm{Cu}$ and $\mathrm{Ni}-40 \mathrm{Cu}$ substrates when soldering at $250{ }^{\circ} \mathrm{C}$. Similar to the reaction product formed in the $\mathrm{Sn}-\mathrm{Zn} / \mathrm{Ni}$ joint [21,36], $\mathrm{Ni}_{5} \mathrm{Zn}_{21}$ is still the first formed product in the $\mathrm{Sn}-\mathrm{Zn} / \mathrm{Ni}-20 \mathrm{Cu}$ and $\mathrm{Sn}-\mathrm{Zn} / \mathrm{Ni}-40 \mathrm{Cu}$ joints.

By contrast, if both elements in the binary substrate can provide successive supplement toward the reaction zone, then a bi-layered IMC structure would occur at first. The diffusivity of reactants in the reaction zone was dependent upon the content and temperature. The $\mathrm{Ni}_{2} \mathrm{Sn}_{2} \mathrm{Zn}+\mathrm{Cu}_{5} \mathrm{Zn}_{8}$ bi-layered IMC structure only appeared in the $\mathrm{Sn}-\mathrm{Zn} / \mathrm{Ni}-60 \mathrm{Cu}$ joint after soldering at $250{ }^{\circ} \mathrm{C}$. This result indicated that binary substrate with suitable content can provide successive supplement of both elements toward the reaction zone. This suitable substrate composition range would increase with the increment of soldering temperature. Given that the diffusion coefficient of atomic will dramatically increase with increased temperature, the $\mathrm{Ni}_{2} \mathrm{Sn}_{2} \mathrm{Zn}+\mathrm{Cu}_{5} \mathrm{Zn}_{8}$ bi-layer was formed first at $350{ }^{\circ} \mathrm{C}$ when the $\mathrm{Cu}$ content in the Ni-Cu substrate ranged from $20 \%$ to $80 \%$.

The new reaction products (mainly $\mathrm{Ni}_{2} \mathrm{Sn}_{2} \mathrm{Zn}$ ) occurred when soldering time was prolonged; thus, the original reaction product is no longer in local equilibrium after reacting at a sufficiently long time $[24,37]$. The formation of $\mathrm{Ni}_{2} \mathrm{Sn}_{2} \mathrm{Zn}$ phase between $\mathrm{Ni}$ and $\mathrm{Ni}_{5} \mathrm{Zn}_{21}$ was also reported in $\mathrm{Sn}-\mathrm{Zn} / \mathrm{Ni}$ joint after prolonged soldering time [15]. In the present work, the $\mathrm{Zn}$ in solder is depleted in a later reaction stage, while the products formed in the early stage react with liquid solder (mainly Sn) and new phases appear. The $\mathrm{Ni}_{5} \mathrm{Zn}_{21}$ phase transferred to $\mathrm{Ni}_{2} \mathrm{Sn}_{2} \mathrm{Zn}$, and $\mathrm{Cu}_{5} \mathrm{Zn}_{8}$ phase transferred to $\mathrm{Ni}_{2} \mathrm{Sn}_{2} \mathrm{Zn}$ and $\mathrm{CuZn}$ when the reaction time at $250{ }^{\circ} \mathrm{C}$ was prolonged.

In brief, when soldering with $\mathrm{Sn}-\mathrm{Zn}$ solder, $\mathrm{Ni}(\mathrm{Cu})$ solid solution substrate can optimize the morphologies of $\mathrm{Ni}_{5} \mathrm{Zn}_{21}$ and $\mathrm{Cu}_{5} \mathrm{Zn}_{8}$ at the interface, and a thin and uniform reaction layer consisting of fine IMC grains can be obtained. Various reaction product combinations were formed at the interface, that is, $\mathrm{Ni}_{2} \mathrm{Sn}_{2} \mathrm{Zn}+\mathrm{Cu}_{5} \mathrm{Zn}_{8}$. The formation of thin $\mathrm{Ni}_{2} \mathrm{Sn}_{2} \mathrm{Zn}$ layer near the substrate enhances the joint reliability [15]. Hence, the adoption of $\mathrm{Ni}(\mathrm{Cu})$ solid solution substrate will provide an effective way to improve the joint reliability of the Sn-Zn soldering system.

\section{Conclusions}

1. When soldered at $250{ }^{\circ} \mathrm{C}$, fine-grained $\mathrm{Ni}_{5} \mathrm{Zn}_{21}$ was the first formed product in $\mathrm{Sn}-\mathrm{Zn} / \mathrm{Ni}-20 \mathrm{Cu}$ and $\mathrm{Sn}-\mathrm{Zn} / \mathrm{Ni}-40 \mathrm{Cu}$ joints, while $\mathrm{Ni}_{2} \mathrm{Sn}_{2} \mathrm{Zn}+\mathrm{Cu}_{5} \mathrm{Zn}_{8}$ and fine-grained $\mathrm{Cu}_{5} \mathrm{Zn}_{8}$ phases were formed in $\mathrm{Sn}-\mathrm{Zn} / \mathrm{Ni}-60 \mathrm{Cu}$ and $\mathrm{Sn}-\mathrm{Zn} / \mathrm{Ni}-80 \mathrm{Cu}$ joints, respectively. $\mathrm{Ni}_{5} \mathrm{Zn}_{21}$ layer transferred to $\mathrm{Ni}_{2} \mathrm{Sn}_{2} \mathrm{Zn}$ phase, whereas $\mathrm{Cu}_{5} \mathrm{Zn}_{8}$ phase transferred to $\mathrm{Ni}_{2} \mathrm{Sn}_{2} \mathrm{Zn}$ and $\mathrm{CuZn}$ phases at prolonged reaction time.

2. $\mathrm{Ni}_{2} \mathrm{Sn}_{2} \mathrm{Zn}+\mathrm{Cu}_{5} \mathrm{Zn}_{8}$ bi-layered structure was always formed first in $\mathrm{Sn}-\mathrm{Zn} / \mathrm{Ni}(\mathrm{Cu})$ joint at $350{ }^{\circ} \mathrm{C}$ regardless of the $\mathrm{Cu}$ content in $\mathrm{Ni}(\mathrm{Cu})$ substrate $(20-80 \%)$. However, the bi-layered $\mathrm{Ni}_{2} \mathrm{Sn}_{2} \mathrm{Zn}+\mathrm{Cu}_{5} \mathrm{Zn}_{8}$ transferred to a loose $\mathrm{Ni}_{3} \mathrm{Sn}_{4}$ layer in the $\mathrm{Sn}-\mathrm{Zn} / \mathrm{Ni}-20 \mathrm{Cu}$ joint, whereas a $\mathrm{Ni}_{2} \mathrm{Sn}_{2} \mathrm{Zn}$ layer transferred in $\mathrm{Sn}-\mathrm{Zn} / \mathrm{Ni}-40 \mathrm{Cu}$ joint. Meanwhile, $\mathrm{Ni}_{2} \mathrm{Sn}_{2} \mathrm{Zn}$ and $\mathrm{CuZn}$ transferred in $\mathrm{Sn}-\mathrm{Zn} / \mathrm{Ni}-60 \mathrm{Cu}$ and $\mathrm{Sn}-\mathrm{Zn} / \mathrm{Ni}-80 \mathrm{Cu}$ joints when the reaction time was prolonged at $350{ }^{\circ} \mathrm{C}$.

3. Using $\mathrm{Ni}(\mathrm{Cu})$ solid solution substrates, the morphologies of $\mathrm{Ni}_{5} \mathrm{Zn}_{21}$ and $\mathrm{Cu}_{5} \mathrm{Zn}_{8}$ can be optimized, and various reaction product combinations can be obtained at the interface. These results would provide an effective way to improve the joint reliability of the $\mathrm{Sn}-\mathrm{Zn}$ soldering system. 
Author Contributions: Research program design, writing-review and editing, X.Z.; data collection and analysis, writing-original draft preparation, J.P.; provided guidance and assistance in the experiments, X.W.; participates in research and data collection, P.Y. and F.W.

Funding: This research was funded by the Shaanxi Province Science and Technology Key Project, grant number 2016NY-137, the Fundamental Research Funds for the Central Universities, grant number 2452017132, 2452016075 and the National Major Science and Technology Project of China, grant number 2017YFB0305700.

Conflicts of Interest: The authors declare no conflicts of interest.

\section{References}

1. Guo, W.; Luan, T.; He, J.; Yan, J. Ultrasonic-assisted soldering of fine-grained 7034 aluminum alloy using Sn-Zn solders below $300{ }^{\circ} \mathrm{C}$. Ultrason. Sonochem. 2018, 40, 815-821. [CrossRef] [PubMed]

2. Luan, T.; Guo, W.; Yang, S.; Ma, Z.; He, J.; Yan, J. Effect of intermetallic compounds on mechanical properties of copper joints ultrasonic-soldered with Sn-Zn alloy. J. Mater. Process. Technol. 2017, 248, 123-129. [CrossRef]

3. Zhang, L.; Xue, S.B.; Gao, L.L.; Sheng, Z.; Ye, H.; Xiao, Z.X.; Zeng, G.; Chen, Y.; Yu, S.L. Development of Sn-Zn lead-free solders bearing alloying elements. J. Mater. Sci. -Mater. Electron. 2009, 21, 1-15. [CrossRef]

4. Liou, W.-k.; Yen, Y.-W.; Jao, C.-C. Interfacial Reactions of Sn-9Zn- $x \mathrm{Cu}(x=1,4,7,10)$ Solders with Ni Substrates. J. Electron. Mater. 2009, 38, 2222-2227. [CrossRef]

5. Zhao, N.; Zhong, Y.; Huang, M.L.; Dong, W.; Ma, H.T.; Wang, Y.P. In situ study on interfacial reactions of $\mathrm{Cu} / \mathrm{Sn}-9 \mathrm{Zn} / \mathrm{Cu}$ solder joints under temperature gradient. J. Alloys Compd. 2016, 682, 1-6. [CrossRef]

6. Yoon, J.-W.; Jung, S.-B. Reliability studies of $\mathrm{Sn}-9 \mathrm{Zn} / \mathrm{Cu}$ solder joints with aging treatment. J. Alloys Compd. 2006, 407, 141-149. [CrossRef]

7. Zhu, W.; Liu, H.; Wang, J.; Ma, G.; Jin, Z. Interfacial Reactions Between Sn-Zn Alloys and Ni Substrates. J. Electron. Mater. 2009, 39, 209-214. [CrossRef]

8. Laurila, T.; Vuorinen, V.; Kivilahti, J.K. Interfacial reactions between lead-free solders and common base materials. Mater. Sci. Eng. R Rep. 2005, 49, 1-60. [CrossRef]

9. Tu, K.; Liu, Y. Recent advances on kinetic analysis of solder joint reactions in 3D IC packaging technology. Mater. Sci. Eng. R Rep. 2019, 136, 1-12. [CrossRef]

10. Kao, C.R.; Chang, Y.A. A theoretical analysis for the formation of periodic layered structure in ternary diffusion couples involving a displacement type of reactions. Acta Metall. Mater. 1993, 41, 3463-3472. [CrossRef]

11. Wang, J.Y.; Lin, C.F.; Chen, C.M. Retarding the $\mathrm{Cu}_{5} \mathrm{Zn}_{8}$ phase fracture at the Sn-9wt.\% Zn/Cu interface. Scr. Mater. 2011, 64, 633-636. [CrossRef]

12. Liu, J.-C.; Wang, Z.-H.; Xie, J.-Y.; Ma, J.-S.; Shi, Q.-Y.; Zhang, G.; Suganuma, K. Effects of intermetallic-forming element additions on microstructure and corrosion behavior of Sn-Zn solder alloys. Corros. Sci. 2016, 112, 150-159. [CrossRef]

13. Liu, J.-C.; Zhang, G.; Ma, J.-S.; Suganuma, K. Ti addition to enhance corrosion resistance of Sn-Zn solder alloy by tailoring microstructure. J. Alloys Compd. 2015, 644, 113-118. [CrossRef]

14. Hu, Y.-h.; Xue, S.-b.; Wang, H.; Ye, H.; Xiao, Z.-x.; Gao, L.-1. Effects of rare earth element Nd on the solderability and microstructure of Sn-Zn lead-free solder. J. Mater. Sci. -Mater. Electron. 2010, 22, 481-487. [CrossRef]

15. Li, J.; Peng, J.; Wang, R.; Feng, Y.; Peng, C. Effects of Co addition on shear strength and interfacial microstructure of Sn-Zn-(Co)/Ni joints. J. Mater. Sci. -Mater. Electron. 2018, 29, 19901-19908. [CrossRef]

16. Ren, G.; Wilding, I.J.; Collins, M.N. Alloying influences on low melt temperature SnZn and SnBi solder alloys for electronic interconnections. J. Alloys Compd. 2016, 665, 251-260. [CrossRef]

17. Huang, Y.C.; Chen, S.W. Co alloying and size effects on solidification and interfacial reactions in the Sn-Zn-(Co)/Cu couples. J. Mater. Res. 2010, 25, 2430-2438. [CrossRef]

18. Huang, M.; Hou, X.; Kang, N.; Yang, Y. Microstructure and interfacial reaction of Sn-Zn-X (Al, Ag) near-eutectic solders on $\mathrm{Al}$ and $\mathrm{Cu}$ substrates. J. Mater. Sci. -Mater. Electron. 2014, 25, 2311-2319. [CrossRef]

19. Maeshima, T.; Ikehata, H.; Terui, K.; Sakamoto, Y. Effect of Ni to the Cu substrate on the interfacial reaction with Sn-Cu solder. Mater. Des. 2016, 103, 106-113. [CrossRef]

20. Peng, J.; Wang, R.C.; Wang, M.; Liu, H.S. Interfacial Microstructure Evolution and Shear Behavior of Au-Sn/Ni- $x$ Cu Joints at $350{ }^{\circ}$ C. J. Electron. Mater. 2017, 46, 2021-2029. [CrossRef] 
21. Lin, H.-f.; Chang, Y.-c.; Chen, C.-c. Sn-Zn/Ni-Co Interfacial Reactions at $250^{\circ}$ C. J. Electron. Mater. 2014, 43, 3333-3340. [CrossRef]

22. Huang, K.C.; Shieu, F.S.; Huang, T.S.; Lu, C.T.; Chen, C.W.; Tseng, H.W.; Cheng, S.L.; Liu, C.Y. Study of Interfacial Reactions Between $\mathrm{Sn}(\mathrm{Cu})$ Solders and Ni-Co Alloy Layers. J. Electron. Mater. 2010, 39, 2403-2411. [CrossRef]

23. Chen, C.-C.; Chan, Y.-T.; Chen, Y.-T. Interfacial reactions between Sn-Cu solders and Ni-Co alloys at $250^{\circ} \mathrm{C}$. Int. J. Mater. Res. 2011, 25, 1321-1328. [CrossRef]

24. Chen, C.-c.; Chen, Y.-t. Alternating reaction phases in $\mathrm{Sn}-\mathrm{Cu} / \mathrm{Ni}-\mathrm{Co}$ solid-state reactions. J. Alloys Compd. 2012, 545, 28-31. [CrossRef]

25. Schmetterer, C.; Rajamohan, D.; Ipser, H.; Flandorfer, H. The high-temperature phase equilibria of the $\mathrm{Ni}-\mathrm{Sn}-\mathrm{Zn}$ system: Isothermal sections. Intermetallics 2011, 19, 1489-1501. [CrossRef] [PubMed]

26. Schmetterer, C.; Rajamohan, D.; Effenberger, H.S.; Flandorfer, $\mathrm{H} \mathrm{Ni}_{2} \mathrm{Sn}_{2} \mathrm{Zn}$ from single-crystal X-ray diffraction. Acta Crystallogr. Sect. C Cryst. Struct. Commun. 2012, 68, i65-i67. [CrossRef]

27. Gandova, V.; Soares, D.; Lilova, K.; Tedenac, J.C.; Vassilev, G.P. Phase equilibria in the Sn-Zn-Ni system. Int. J. Mater. Res. 2011, 102, 257. [CrossRef]

28. Gandova, V.; Vassilev, G.P. Thermodynamic optimization and phase equilibria in the ternary system Ni-Sn-Zn. J. Alloys Compd. 2014, 609, 1-6. [CrossRef]

29. Chang, J.; Seo, S.-K.; Lee, H.M. Phase Equilibria in the Sn-Ni-Zn Ternary System: Isothermal Sections at $200{ }^{\circ} \mathrm{C}, 500{ }^{\circ} \mathrm{C}$, and $800{ }^{\circ} \mathrm{C}$. J. Electron. Mater. 2010, 39, 2643-2652. [CrossRef]

30. Liang, J.-L.; Du, Y.; Tang, Y.-Y.; Xie, S.-B.; Xu, H.-H.; Zeng, L.-M.; Liu, Y.; Zhu, Q.-M.; Nong, L.-Q. Phase Equilibria in the Ni-Sn-Zn System at $500{ }^{\circ} \mathrm{C}$. J. Electron. Mater. 2011, 40, 2290-2299. [CrossRef]

31. Chen, S.-w.; Hsu, C.-m.; Chou, C.-y.; Hsu, C.-w. Isothermal section of ternary Sn-Zn-Ni phase equilibria at $250{ }^{\circ}$ C. Prog. Nat. Sci. Mater. Int. 2011, 21, 386-391. [CrossRef]

32. Wołczyński, W.; Okane, T.; Senderowski, C.; Zasada, D.; Kania, B.; Janczak-Rusch, J. Thermodynamic justification for the $\mathrm{Ni} / \mathrm{Al} / \mathrm{Ni}$ joint formation by a diffusion brazing. Int. J. Thermodyn. 2011, 14, 97-105. [CrossRef]

33. Wołczyński, W.; Okane, T.; Senderowski, C.; Kania, B.; Zasada, D.; Janczak-Rusch, J. Meta-stable conditions of diffusion brazing. Arch. Metall. Mater. 2011, 56, 311-323. [CrossRef]

34. Huang, Y.-c.; Chen, S.-w.; Chou, C.-y.; Gierlotka, W. Liquidus projection and thermodynamic modeling of Sn-Zn-Cu ternary system. J. Alloys Compd. 2009, 477, 283-290. [CrossRef]

35. Sun, Y.; Liu, H.; Xie, Z.; Jin, Z. Prediction of interfacial reaction products between metals with same lattice structure through thermodynamic modeling. CALPHAD 2016, 52, 180-185. [CrossRef]

36. Chan, Y.C.; Chiu, M.Y.; Chuang, T.H. Intermetallic Compounds Formed during the Soldering Reactions of Eutectic Sn-9Zn with Cu and Ni Substrates. Zeitschrift Für Metallkunde 2002, 93, 95-98. [CrossRef]

37. Chen, W.M.; Yang, S.C.; Tsai, M.H.; Kao, C.R. Uncovering the driving force for massive spalling in the $\mathrm{Sn}-\mathrm{Cu} / \mathrm{Ni}$ system. Scr. Mater. 2010, 63, 47-49. [CrossRef]

(C) 2019 by the authors. Licensee MDPI, Basel, Switzerland. This article is an open access article distributed under the terms and conditions of the Creative Commons Attribution (CC BY) license (http://creativecommons.org/licenses/by/4.0/). 